\title{
Paying Up for Fair Pay: Consumers Prefer Firms with Lower CEO-to-Worker Pay Ratios
}

\section{Citation}

Mohan, Bhavya, Michael I. Norton, and Rohit Deshpandé. "Paying Up for Fair Pay: Consumers Prefer Firms with Lower CEO-to-Worker Pay Ratios." Harvard Business School Working Paper, No. 15-091, May 2015.

\section{Permanent link}

http://nrs.harvard.edu/urn-3:HUL.InstRepos:16080249

\section{Terms of Use}

This article was downloaded from Harvard University's DASH repository, and is made available under the terms and conditions applicable to Open Access Policy Articles, as set forth at http:// nrs.harvard.edu/urn-3:HUL.InstRepos:dash.current.terms-of-use\#OAP

\section{Share Your Story}

The Harvard community has made this article openly available.

Please share how this access benefits you. Submit a story.

Accessibility 


\section{Paying Up for Fair Pay: Consumers Prefer Firms with Lower CEO-to- Worker Pay Ratios}

Bhavya Mohan Michael I. Norton Rohit Deshpandé

Working Paper 15-091 


\section{Paying Up for Fair Pay: Consumers Prefer Firms with Lower CEO-to- Worker Pay Ratios}

Bhavya Mohan

Harvard Business School

Michael I. Norton

Harvard Business School

Rohit Deshpandé

Harvard Business School

Working Paper 15-091 
Paying Up for Fair Pay:

Consumers Prefer Firms with Lower CEO-to-Worker Pay Ratios

Bhavya Mohan, Michael I. Norton, and Rohit Deshpandé

Harvard Business School 


\section{ABSTRACT}

Prior research examining consumer expectations of equity and price fairness has not addressed wage fairness, as measured by a firm's pay ratio. Pending legislation will require American public companies to disclose the pay ratio of $\mathrm{CEO}$ wage to the average employee's wage. Our six studies show that pay ratio disclosure affects purchase intention of consumers via perceptions of wage fairness. The disclosure of a retailer's high pay ratio (e.g., 1000 to 1 ) reduces purchase intention relative to firms with lower ratios (e.g., 5 to 1 or 60 to 1 , Studies $1 \mathrm{~A}, 1 \mathrm{~B}$, and 1C). Lower pay ratios improve consumer perceptions across a range of products at different price points (Study 2A and 2B), increase consumer ratings of both firm warmth and firm competence (Study 3), and enhance perceptions of Democrats and Independents without alienating Republican consumers (Study 4). A firm with a high ratio must offer a 50\% price discount to garner as favorable consumer impressions as a firm that charges full price but features a lower ratio (Study 5).

Keywords: pay ratio, wage fairness, purchase intention, customers, financial disclosure 


\section{INTRODUCTION}

On July 21, 2010, hours before the Dodd-Frank Wall Street Reform Act was signed into federal law, a last-minute addition was made to the 2300 page bill (Davidoff 2013). The seven lines of Section 953(b) decreed that all public companies disclose the following in their annual reports and proxy statements: "A) the median of the annual total compensation of all employees of the issuer, except the chief executive officer (or any equivalent position) of the issuer; (B) the annual total compensation of the chief executive officer (or any equivalent position) of the issuer; and (C) the ratio of the amount described in subparagraph (A) to the amount described in subparagraph (B)" (“The Dodd-Frank Act" 2010). Five years later, this section of the law has yet to be adopted as a formal rule by the Securities and Exchange Commission (SEC; Ross Sorkin 2015). Should the law be implemented, what would the likely impact on consumer behavior be? And even in the absence of a legal requirement, could there be benefits for some firms in disclosing their (low) pay ratios to consumers?

For obvious reasons, the pay ratio of CEOs to average workers has long been a question of interest to both employees and investors. Management guru Peter Drucker, for example, argued that the ratio of a CEOs salary to average worker salary should be capped at 25 to 1 , and that greater disparity would lead to employee resentment and decreased morale, negatively affecting company performance (McGregor 2013). Yet a recent investigation conducted by the New York Times estimates that the pay ratio of total CEO compensation to median employee wage at a public company was as high as 2,238 to 1 in 2014, unbeknownst to investors (Morgensen 2015). While pay ratios are of direct 
material interest to investors and employees, we explore the effects of high pay ratios in a different context: the relationship between firms and customers.

In fact, a "natural experiment" offers initial evidence that pay ratios are of interest not only to investors and employees, but also consumers. On October 13, 2013, the SEC posted a request for public comment on the proposed pay ratio disclosure rule; the SEC received over 126,000 public comments, which were classified into eight letter types and posted online ("Comments on Pay Ratio Disclosure" 2013). Comment Letter Type A, for instance, contained the following text: "Disclosing corporate pay ratios between CEOs and average employees will discourage the outrageous and reckless pay practices that fueled the 2008 crash. Knowing which corporations heap riches upon their executives while squeezing struggling employees also will be a useful factor for me when considering which businesses to support with my consumer and investment dollars." Notably, this letter explicitly includes the term "consumer" in addition to the terms "investor" and "employee." In fact, by our analysis, more than $25 \%$ of the comment letters used the term "consumer."

This motivates our prediction that consumer purchase behavior will be influenced by the disclosure of a firm's pay ratio. Specifically, across six studies we test whether disclosing pay ratios of a retailer adversely affects customer attitudes and behaviors towards retailers with high ratios (e.g., 1000 to 1) compared to those with ratios they perceive to reflect fairer wages (e.g., 60 to 1). 
But what is a "fair" wage ratio, that would induce positive consumer perceptions - or an "unfair" ratio that might induce negative perceptions? Previous research suggests that consumers believe CEO pays ratios are far lower than they actually are; in fact, consumers' ideal ratio of CEO pay to average unskilled worker is 4.6 to 1 , while their estimated actual ratio of CEO pay to average unskilled worker pay is 10 to 1 (Kiatpongsan and Norton 2014). Note that this ideal ratio is far lower than the average pay ratio across US firms, which is estimated to be approximately 331 to 1 (AFL-CIO 2014); indeed, one recent study uncovered large public firms with pay ratios ranging from 284 to 1 to 2239 to 1 , when taking into account the value of base salary, cash bonuses, perquisites and the grant-date value of stock and option grants (Morgensen 2015). Importantly, even seemingly similar firms can have dramatically different pay ratios: Walmart's ratio, excluding stock compensation, has been estimated to be close to 1000 to 1, whereas Costco comes in closer to 60 to 1 (Bach 2013; PayScale 2013).

Given that prior work has established an ideal pay ratio far lower than the actual pay ratio of many large American firms, would consumers act differently towards firms with ratios closer to what they perceive to be fair? Certainly, previous research suggests that fairness can play a critical role in shaping consumer behavior. For instance, equity theory suggests that consumers desire an equitable distribution of profits between buyer and seller when interacting with a firm (Darke and Dahl 2003; Huppertz, Arenson, and Evans 2013). Moreover, when consumers believe that a firm is making a large profit on them, they perceive prices as less fair, and in turn are less willing to buy (Campbell 1999; Kahneman, Knetsch, and Thaler 1986; Xia, Monroe, and Cox 2004); in contrast, when prices are perceived to be more fair, firm perceptions are more positive (Bolton, Warlop, 
and Alba 2003). A separate body of work has examined the effects of firm social responsibility relating to an ethical supply chain (Hiscox, Broukhim, and Litwin 2015; Kimeldorf, Meyer, and Robinson 2004; Paharia, Vohs, and Deshpandé 2013). For instance, consumers are willing to pay a $23 \%$ premium for coffee labeled 'Fair Trade' (Hiscox, Broukhim, and Litwin 2015). Given this general sensitivity to issues of fairness, we predict that when consumers are cued with a high pay ratio, their perception of the firm's wage fairness will decrease, subsequently decreasing purchase intention.

Of course, disclosing pay ratios is not without risks. First, it is plausible that the disclosure of a high pay ratio signals higher quality for certain product categories, signaling that a firm that has sufficient money to pay an astronomical CEO wage may also have the funds to devote to increased product quality - and therefore that goods made by firms with lower pay ratios may be perceived as of lower quality. Akin to the finding that chocolate fudge tastes better to consumers when they are told that it was produced using an expensive machine (Chinander and Schweitzer 2003), consumers may feel that products produced by firms with expensive CEOs are superior. To address this risk, we explore whether the effect of a retailer's pay ratio disclosure on consumer intention to buy holds for a wide variety of products, and even for products whose quality is outside of that retailer's purview - such as a gift certificate to a different retailer (Okada 2005).

Second, it is possible that a low pay ratio may signal that a company is "warm and fuzzy" - but therefore not competent. Indeed, consumers are less willing to buy identical products made by non-profit versus for-profit firms, precisely because non-profits are seen as more 'warm' and less 'competent' (Aaker, Vohs, and Mogilner 2010). Given the 
perception of non-profit competence, it is plausible that a firm is seen as seen less 'competent' if it pays its CEO a low wage. To address this risk, we assess this possible tradeoff between warmth and competence in the domain of pay ratios. Note that a firm with a low pay ratio could be seen as both warm (for treating its workers relatively well) and competent (for not over-compensating the $\mathrm{CEO}$ ), such that firms with low pay ratios may not experience the same tradeoffs as non-profits.

Third, it is possible that while disclosing low pay ratios improves perceptions of some consumers, it may alienate other consumers; in particular, liberal Americans are more likely to support increases in the minimum wage (and therefore lower pay ratios) than conservative Americans (Kuziemko et al. 2015). Given the central role that ideology plays in consumption (Crockett and Wallendorf 2004; Hirschman 1993) and the fact that different persuasive messages have different appeal to different political affiliations (Kidwell, Farmer, and Hardesty 2013; Winterich, Zhang, and Mittal 2012), it is possible that while low pay ratios may appeal to liberal consumers, they may serve as a deterrent to more conservative consumers. At the same time, both liberal and conservative Americans' ideal pay ratios are far lower than current actual pay ratios (Kiatpongsan and Norton 2014), suggesting the possibility that low pay ratios may improve firm perceptions more broadly.

\section{OVERVIEW OF STUDIES}

We examine when and why consumers reward or punish firms for their ratio of CEO pay to the pay of their average employee. In six experiments, participants answer 
questions about shopping scenarios for different products. We first examine whether disclosure of a high pay ratio versus a lower pay ratio leads to decreased willingness to buy and willingness to pay for products, whether shopping at only one retailer (Studies 1A and 1B) or comparison shopping between high- and low-pay-ratio retailers (Study 1C). We next assess these effects across hedonic and utilitarian goods, while controlling for possible inferences about different product types, different prices, and the quality of the retailer's goods (Study 2A and 2B). We then explore whether disclosure of a low pay ratio positively increases consumer perception of firm warmth without sacrificing perceptions of firm competence (Study 3), and whether disclosure alienates certain consumer subgroups (Study 4). Finally, we explore the practical significance of these effects, assessing the percentage discount that high-pay-ratio retailers would need to offer in order to compete with low-pay-ratio retailers (Study 5). Across the studies, we assess perceptions of wage fairness in order to demonstrate a mediating role of wage fairness on consumer decisions. We conclude by discussing the implications of these findings for firms and policy makers, and possible future research directions.

\section{STUDY 1A: HIGH AND LOW (IDEAL) PAY RATIOS}

Study 1A offers an initial test of the effect of disclosing a "high" versus "low" pay ratio on consumer willingness to pay. Moreover, we assess perceptions of wage fairness to examine whether these perceptions track with pay ratios, and mediate the influence of ratios on purchase intentions. 
Participants were given a description of a product (a towel set), and told the listed retail price for the towel. (A similar product sold online by a major American retailer informed the product description and retail price.) Between subjects, we varied pay ratio, by disclosing either a low (5 to 1$)$ or high (1000 to 1 ) ratio of CEO compensation to median employee wage. To estimate employee wage, $\mathrm{CEO}$ wage, and the resulting ratio for the high pay ratio, we used publicly available data, compiled by a firm that collects employee wage data at Fortune 100 firms (Bach 2013). Our high pay ratio $(\$ 24,000,000$ to $\$ 22,400$, or 1000 to 1 ) reflects the estimated CEO cash compensation, median employee cash compensation, and resulting pay ratio of a large American retailerWalmart, although participants were not informed of this fact (PayScale 2013). To create our low pay ratio, we held median employee pay constant at $\$ 22,400$, and calculated the CEO salary to reflect the ideal pay ratio of a CEO's wage to the average worker's wage of approximately 5 to 1 demonstrated in previous research (Kiatpongsan and Norton 2014).

\section{Method}

Design and Procedure. Participants $\left(N=406, M_{\text {age }}=30.6,65.8 \%\right.$ male $)$ completed this online experiment in exchange for $\$ 0.30$. Participants were randomly assigned to one of 2 experimental conditions between subjects: "High ratio" (1000 to 1 pay ratio) or "Low ratio" (5 to 1 pay ratio).

All participants were provided with the following scenario: "Imagine that you are looking to purchase a new set of towels, to replace a worn out set you currently have. You find a set of 2 high-quality, 100\% Turkish cotton towels. Each towel in the set is 
oversized (34" by 68 "). The towel set has a listed retail price of $\$ 50.00$, but sometimes goes on sale. A well-known general merchandise retailer, with both retail locations and an online store, sells the towels." On the next page, in the high ratio condition, participants were told: "You learn that the retailer pays the average employee $\$ 22,400$. The retailer pays the CEO $\$ 24,000,000$. The ratio of the CEO's salary to the average employee's salary is 1000 to $1 . "$ In the low ratio condition, participants were told: "You learn that the retailer pays the average employee $\$ 22,400$. The retailer pays the CEO $\$ 112,000$. The ratio of the CEO's salary to the average employee's salary is 5 to $1 . ”$ Dependent Measures: Participants indicated their willingness to pay for the towels by indicating a dollar amount in response to an open-ended question: "What is the most you would be willing to pay for this towel set?" Participants also indicated their perception of wage fairness on a 7-point scale (1: Not at all fair, 7: Very fair): "How fair do you think the wages that this retailer pays its employees are?"

All experiments concluded with demographic questions. Participants indicated their gender (male, female), age, highest level of education completed (some high school, high school graduate, some college, college graduate, postgraduate), and combined annual household income.

We set the desired number of participants at the outset of each experiment and did not analyze the data until that number was reached. We report all manipulations and measures. In Experiment 1A, we excluded one participant who listed a willingness to pay above $\$ 240$, since this was above the highest retail price $(\$ 120)$ we could find online for a single towel sold by a mainstream retailer. 
Results

Willingness to Pay. As predicted, willingness to pay for the product from the high ratio firm was significantly lower than from the low ratio firm $\left(M_{\text {low }}=29.33, S D=15.01\right.$ vs. $\left.M_{\text {high }}=25.51, S D=13.51 ; t(403)=2.67, p<0.01\right)$. Gender, education, age, and income did not change this result when added to the model as covariates; including all four as covariates, for example, the effect of pay ratios remained significant, $F(1,399)=$ 5.66, $p=0.02$ ). Throughout the rest of our experiments all reported results remain substantively the same when controlling for these demographic variables (gender, education, age, and income).

Wage Fairness. Also as predicted, perceived wage fairness was significantly lower for the firm with the high pay ratio than the firm with the low pay ratio $\left(M_{\text {high }}=\right.$ $2.34, S D=1.52$ vs. $\left.M_{\text {low }}=3.77, S D=1.67 ; t(403)=9.03, p<0.01\right)$.

Mediation. The pay ratio condition predicted both willingness to pay $(\beta=-3.83, p$ $<0.01)$, as well as wage fairness $(\beta=-1.43, p<0.01)$. When wage fairness and pay ratio condition were both included in the regression model predicting willingness to pay, the effect of wage fairness remained significant $(\beta=1.41, p<0.01)$, and the effect of pay ratio condition was reduced to insignificance $(\beta=-1.81, p=0.24)$, providing support for mediation. A 5,000-sample bootstrap analysis revealed that the 95\% bias-corrected confidence interval for the size of the indirect effect excluded zero [-5.05, -0.95], suggesting a significant indirect effect (Baron and Kenny 1986; Preacher and Hayes 2008).

STUDY 1B: HIGH AND LOW (REAL-WORLD) PAY RATIOS 
Study 1A suggests that revealing that a firm pays its CEO an 'ideal' level of compensation relative to the average employee - a 5 to 1 ratio - leads to a higher willingness to pay for a towel than revealing an 'unfair' level of compensation (a 1000 to 1 ratio). While a 5 to 1 ratio reflects people's ideal ratio, an examination of pay ratios at Fortune 500 companies estimated the lowest pay ratio among retailers to be approximately 58 to 1 - at Costco (PayScale 2013). In Study 1B, we test whether revealing a real-world low pay ratio (60 to 1 ) increases willingness to buy relative to revealing another real-world, but much higher, pay ratio (1000 to 1). As in Study 1A, participants were presented with a product; in this study, however, participants were not given a focal retail price - rather, they were told that the product was priced reasonably, and rated their willingness to buy the product. We varied the pay ratio: participants were randomized to see a product sold by a retailer with either a low (60 to 1) pay ratio or a high (1000 to 1$)$ pay ratio.

\section{Method}

Design and Procedure. Participants $\left(N=156, M_{\text {age }}=35.3,64.7 \%\right.$ male $)$ completed this online experiment in exchange for $\$ 0.30$. Participants were randomly assigned to one of 2 experimental conditions between subjects: "High ratio" (1000 to 1 pay ratio) or a "Low ratio" (60 to 1 pay ratio).

Participants were again told to envision a variation of the towel context used in Study 1A: "Imagine that you are looking to purchase a new set of towels, to replace a worn out set you currently have. You find a set of 2 high-quality, 100\% Turkish cotton 
towels. Each towel in the set is oversized (34" by 68 "). You find a set of towels that you like, at a price point that is below your budget. A well-known general merchandise retailer, with both retail locations and an online store, sells the towels."

In the high ratio condition, participants were told: "You learn that the retailer pays the average employee $\$ 22,400$. The retailer pays the CEO $\$ 24,000,000$. The ratio of the CEO's salary to the average employee's salary is 1000 to $1 . "$ In the low ratio condition, participants were told: "You learn that the retailer pays the average employee $\$ 22,400$. The retailer pays the CEO $\$ 1,344,000$. The ratio of the CEO's salary to the average employee's salary is 60 to $1 . "$

Dependent Measures. To gauge willingness to buy, participants were asked: "Given the opportunity, how likely are you to purchase the towel set from this retailer?" on a 7-point scale (1: Not at all likely, 7: Very likely). Participants also indicated their perception of wage fairness on a 7-point scale (1: Not at all fair, 7: Very fair): "How fair do you think the wages that this retailer pays its employees are?"

Results

Willingness to Buy. Willingness to buy from the high-pay-ratio retailer was significantly lower than from the low-pay-ratio retailer $\left(M_{\text {low }}=4.69, S D=1.61\right.$ vs. $M_{\text {high }}$ $=3.94, S D=1.88 ; t(154)=2.70, p<0.01)$.

Wage fairness. Perceived wage fairness was significantly lower in the high compared to the low pay ratio condition $\left(M_{\text {low }}=3.51, S D=1.72\right.$ vs. $M_{\text {high }}=2.29, S D=$ $1.44 ; t(154)=4.79, p<0.01)$. 
Mediation. Pay ratio condition predicted both willingness to buy $(\beta=-0.76, p<$ $0.01)$, as well as wage fairness $(\beta=1.22, p<0.01)$. When wage fairness and pay ratio condition were both included in the regression model predicting willingness to pay, the effect of wage fairness remained significant $(\beta=0.61, p<0.01)$, but the effect of pay ratio condition was reduced to insignificance $(\beta=-0.02, p=0.94)$, providing support for mediation. A 5,000-sample bootstrap analysis revealed that the $95 \%$ bias-corrected confidence interval for the size of the indirect effect excluded zero [-1.10, -0.42], suggesting a significant indirect effect (Baron and Kenny 1986; Preacher and Hayes 2008).

STUDY IC: COMPARING HIGH-AND LOW-PAY-RATIO RETAILERS DIRECTLY

Consumers in both Studies 1A and 1B considered only one retailer, but much real-world shopping involves comparing products across retailers. Coupled with the fact that consumers generally assess the value of products differently when assessing them jointly versus together (Hsee 1996), we designed Study 1C to provide a within-subjects test of the effects of pay ratios. Consumers evaluate two identical towels sold by two different retailers, as opposed to the separate evaluation in the prior studies. We examine when consumers are willing to pay a premium to purchase products sold by retailers with a low pay ratio.

\section{Method}


Design and Procedure. Participants $\left(N=101, M_{\text {age }}=31.7,60.4 \%\right.$ male $)$

completed this online experiment in exchange for \$0.30. Participants were told: "Imagine that you are looking to purchase a new set of towels, to replace a worn out set you currently have. You find a set of 2 high-quality, 100\% Turkish cotton towels. Each towel in the set is oversized (34" by 68"). Two well-known general merchandise retailers sell the towel set. Retailer A pays the average employee $\$ 22,400$, and the CEO $\$ 24,000,000-$ the ratio of the CEO's salary to the average employee's salary is 1000 to 1 . Retailer B pays the average employee $\$ 22,400$ and the CEO $\$ 112,000$ - the ratio of the CEO's salary to the average employee's salary is 5 to 1. Retailer A sells the set of towels for $\$ 25.00 . "$

Dependent Measures. Participants were asked, "Would you be willing to pay more than $\$ 25$ in order to buy the towels from Retailer B? (Yes/No).” Then, participants completed an open-ended question: "Please indicate the amount you'd be willing to pay to buy the towels from Retailer B.” Finally, participants indicated their perception of wage fairness on a 7-point scale (1: Not at all fair, 7: Very fair) for both retailers: "How fair do you think the wages that retailer $[\mathrm{A} / \mathrm{B}]$ pays its employees are?"

\section{Results}

Some $32.7 \%$ of participants stated that they would be willing to pay more than $\$ 25$ in order to buy the towels from Retailer B. Replicating Study 1A, participants were willing to pay more to buy the towel from Retailer B than the retail price of $\$ 25.00$ listed by Retailer A $\left(M_{w t p B}=26.97, S D=8.98 ; t(100)=2.21, p=0.03\right)$. Finally, participants 
rated Retailer B as paying a fairer wage than Retailer A $\left(M_{\text {fair }}=2.97, S D=1.85\right.$ vs. $\left.M_{\text {fair } B}=5.05 S D=1.44 ; t(100)=9.37, p<0.01\right)$.

STUDY 2A: PAY RATIOS ACROSS CATEGORY AND PRICE

Studies 1A, 1B, and 1C demonstrate the benefits of low pay ratios on consumers' willingness to pay and interest in purchasing, for one product type. In Studies 2A and 2B we investigate whether the positive effects hold across product types varying in price (Study 2A), and whether the effect holds when we control for inferences about product quality by standardizing retail value (Study 2B).

Study 2A has two primary goals. First, we test whether the effect of disclosing a high pay ratio holds across different products and price points - ranging from a $\$ 3.99$ box of cereal to a $\$ 499.99$ flat screen television. Second, we also test whether the effect of disclosing a high pay ratio holds in the absence of revealing the specific CEO wage and employee wage paid out by the firm: do customers need to see the actual dollar amounts that CEOs make, or is merely viewing the ratio of CEO pay to employee pay sufficient to trigger reactions?

\section{Method}

Design and Procedure. Participants $\left(N=151, M_{\text {age }}=30.2,66.2 \%\right.$ male $)$ completed this online experiment in exchange for $\$ 0.30$. We used a 2(Pay Ratio: High vs. Low) by 10 (Product category: stereo headphones, 50" flat screen television, book, 16quart cooking pot, 80 pack of garbage bags, 5' floor lamp, 21 oz. cereal box, 8 AA 
battery pack, 2 bath towels, bag-less upright vacuum cleaner) mixed factorial design. All participants were told: "Imagine you are shopping at well-known general merchandise retailer, with both retail locations and an online store." Pay ratio was again manipulated between subjects. In the high ratio condition, participants were told, "You learn that at this retailer, the ratio of the CEO's salary to the average employee's salary is 1000 to $1 . "$ In the low ratio condition, participants were told, "You learn that at this retailer, the ratio of the CEO's salary to the average employee's salary is 5 to 1. ." Each participant subsequently assessed their willingness to buy products from 10 different product categories. For each product, participants were told, "You come across [product], at a price that is below your budget." Each product was assessed on a separate page, and the 10 products were presented in random order. The products represented a wide range of categories and prices: listed retail prices for similar products sold online ranged from $\$ 3.99$ (cereal box) to $\$ 499.99$ (flat screen television).

Dependent Measures. Participants completed the same willingness to buy measure as in Study 1B.

[Insert Figure 1 About Here]

Results

Willingness to Buy. We conducted a 2(Pay Ratio: High vs. Low) by 10 (Product category: stereo headphones, 50" flat screen television, book, 16-quart cooking pot, 80 pack of garbage bags, 5' floor lamp, 21 oz. cereal box, 8 AA battery pack, 2 bath towels, bag-less upright vacuum cleaner) mixed ANOVA, with willingness to buy as the dependent variable. We first examined the between-subjects effects. We again found a significant main effect on willingness to buy of disclosing a high pay ratio $(F(1,149)=$ 
$5.43, p=0.02)$. Examining the multivariate tests, we unsurprisingly found a significant within-subjects main effect of product category on willingness to buy $(F(9,141)=5.05, p$ $<0.01$ ), denoting that some products were preferable to others. Importantly, the interaction between product type and pay ratio was not significant $(F(9,141)=0.66, \mathrm{p}=$ 0.75 ), indicating that the impact of pay ratio disclosure was not significantly different across product categories. As can be seen in Figure 1, for every product, the trend was such that willingness to buy was higher for the low-pay-ratio retailer.

\section{STUDY 2B: PAY RATIOS AND QUALITY INFERENCES}

In Study 2B we explore a potential downside of disclosing low pay ratios. Although consumers may believe that firms with high pay ratios have unfair wage structures, it is still possible that very high CEO compensation serves as a signal of product quality: if a firm can afford to pay its CEO \$20 million dollars, it may also have the means to manufacture high quality products. (Of course, the opposite inference is also possible: firms that pay their CEOs too much may be taking money away from product quality). In Study 2, we control for variations in product quality by testing whether the impact of pay ratios holds for both hedonic and utilitarian goods with standardized retail value - gift certificates to another retailer (Okada 2005).

Design and Procedure. Participants $\left(N=305, M_{\text {age }}=30.0,67.2 \%\right.$ male $)$ completed this online experiment in exchange for $\$ 0.30$. Participants were randomly 
assigned to one of 4 experimental conditions in a 2 (Pay Ratio: High vs. Low) by 2(Product Category: Hedonic vs. Utilitarian) between-subjects design.

Participants were told to envision one of two shopping contexts, using a manipulation from prior research (Okada 2005). In the utilitarian context, participants were told: “Imagine that a well-known retailer sells a $\$ 50$ grocery certificate to a supermarket that you frequent in your neighborhood." In the hedonic context, participants were told: "Imagine that a well-known retailer sells a $\$ 50$ dining certificate to a restaurant that you frequent in your neighborhood."

In the high ratio condition, participants were told: "You learn that the retailer pays the average employee $\$ 22,400$. The retailer pays the CEO $\$ 24,000,000$. The ratio of the CEO's salary to the average employee's salary is 1000 to 1. " In the low ratio condition, participants were told: "You learn that the retailer pays the average employee $\$ 22,400$. The retailer pays the CEO $\$ 112,000$. The ratio of the CEO's salary to the average employee's salary is 5 to $1 . "$

Dependent Measures. Participants then completed the same willingness to buy and wage fairness measures as in Study 1B.

[Insert Figure 2 About Here]

\section{RESULTS}

Willingness to Buy. We conducted a 2(Pay Ratio: High vs. Low) by 2(Purchase Context: Hedonic vs. Utilitarian) ANOVA on willingness to buy (Figure 2). We again observed a significant effect of pay ratios $(F(1,301)=71.15, p<0.01)$. There was no 
main effect of purchase context $(F(1,301)=0.03, p=0.92)$, and the interaction between ratio discrepancy and purchase context was not significant $(F(1,301)=0.39, p=0.53)$, such that the effect of ratios on preferences held for both hedonic and utilitarian gift cards.

Wage Fairness. We conducted a 2(Pay Ratio: High vs. Low) by 2(Purchase Context: Hedonic vs. Utilitarian) ANOVA on perceptions of wage fairness. There was again a main effect of ratio discrepancy $(F(1,301)=120.66, p<0.01)$. There was no main effect of purchase context $(F(1,301)=0.76, p=0.38)$, and the interaction between ratio discrepancy and purchase context was not significant $(F(1,301)=1.41, p=0.24)$.

Mediation. Once again, pay ratio condition predicted both willingness to buy $(\beta=$ $-1.64, p<0.01)$, as well as wage fairness $(\beta=-2.23, p<0.01)$. When wage fairness and pay ratio condition were both included in the regression model predicting willingness to pay, the effect of wage fairness remained significant $(\beta=0.58, p<0.01)$, but the effect of pay ratio condition was reduced to insignificance $(\beta=-0.34, p=0.14)$, again providing support for mediation. A 5,000-sample bootstrap analysis revealed that the $95 \%$ biascorrected confidence interval for the size of the indirect effect excluded zero [-1.47, 0.90], suggesting a significant indirect effect (Baron and Kenny 1986; Preacher and Hayes 2008).

STUDY 3: PAY RATIOS, WARMTH, AND COMPETENCE

Study 2 demonstrates that the effects of disclosing a high pay ratio on consumer purchase intention occurs even when product quality is held constant, suggesting that 
independent of product quality inferences, low-pay-ratio retailers are preferred. In Study 3 , we explore a potential second risk for firms that disclose a low pay ratio. Prior research shows that consumers assess firms across the dimensions of warmth and competence, with non-profits typically viewed as warm (but incompetent) and for-profits typically viewed as competent (but cold; (Aaker, Vohs, and Mogilner 2010)). In Study 3, we test whether disclosing a low pay ratio leads to similar tradeoffs in perceptions of firm warmth versus firm competence - whether being fair leads to perceptions of being nice, but incompetent.

Method

Design and Procedure. Participants $\left(N=402, M_{\text {age }}=31.5,66.8 \%\right.$ male $)$ completed this online experiment in exchange for $\$ 0.30$. Participants were once again randomly assigned to one of 2 experimental conditions between subjects: "High ratio" (1000 to 1 pay ratio) or a "Low ratio" (5 to 1 pay ratio). The experimental design was identical to Study 1A.

Dependent Measures. The willingness to pay and wage fairness measures were administered as in Study 1A. We excluded one outlier participant, who stated a willingness to pay above $\$ 240$.

In addition, we included measures to gauge perceptions of firm warmth and perceptions of firm competence (Aaker, Vohs, and Mogilner 2010). Participants were asked, "To what extent do you believe that this retailer is __ ?" on a set of 6 traits, presented in randomized order. We summed and averaged the participants' responses to create two indexes. Three traits comprised the warmth index (warm, kind, generous; 
Cronbach's $\alpha=0.93$ ) and three traits comprised the competence index (competent, effective, efficient; Cronbach's $\alpha=0.88$ ).

Results

Willingness to Pay. Replicating our prior studies, willingness to pay in the high ratio condition was significantly lower than in the low ratio condition $\left(M_{\text {high }}=25.84, S D\right.$ $=13.27$ vs. $\left.M_{\text {low }}=28.83, S D=12.79 ; t(399)=2.28, p=0.02\right)$.

Wage Fairness. Perceived wage fairness was significantly lower in the high ratio condition than in the low ratio condition $\left(M_{\text {high }}=2.65, S D=1.61\right.$ vs. $M_{\text {low }}=3.64 S D=$ $1.78 ; t(399)=5.96, p<0.01)$.

Retailer Warmth and Competence. Most importantly for the current study, we observed no tradeoff between warmth and competence for low-pay-ratio retailers. Perceived retailer warmth was significantly lower in the high ratio condition than in the low ratio condition $\left(M_{\text {high }}=2.76 S D=1.35\right.$ vs. $M_{\text {low }}=3.66, S D=1.41 ; t(399)=6.57, p<$ $0.01)$, as was perceived retailer competence $\left(M_{\text {high }}=4.25, S D=1.38\right.$ vs. $M_{\text {low }}=4.66 S D$ $=1.20 ; t(399)=3.10, p<0.01)$.

Mediation. Once again, the pay ratio condition predicted both willingness to pay $(\beta=-2.99, p=0.02)$ and wage fairness $(\beta=-0.99, p<0.01)$. When wage fairness and pay ratio condition were both included in the regression model predicting willingness to pay, the effect of wage fairness remained significant $(\beta=1.65, p<0.01)$, but the effect of pay ratio condition was reduced to insignificance $(\beta=-1.36, p=0.31$ ), again providing support for mediation. A 5,000-sample bootstrap analysis revealed that the $95 \%$ biascorrected confidence interval for the size of the indirect effect excluded zero [-2.58, - 
0.60], suggesting a significant indirect effect (Baron and Kenny 1986; Preacher and Hayes 2008).

STUDY 4: PAY RATIOS AND POLITICAL BELIEFS

Study 3 demonstrates that disclosing a low pay ratio does not lead to tradeoffs in perceptions of firm warmth versus firm competence. In Study 4, we explore a third potential risk for firms that disclose a low pay ratio. Prior research shows that people have varying perceptions of inequality; for instance, Republican voters desire relatively less equal distributions of wealth than their Democratic counterparts (Norton and Ariely 2011). In Study 4, we test whether a low pay ratio will alienate certain customer subgroups, such that even if disclosure increases positive perceptions of some customers, it may harm the firm in the eyes of other customers.

Method

Design and Procedure. Participants $\left(N=253, M_{\text {age }}=33.5,57.7 \%\right.$ male $)$ completed this online experiment in exchange for $\$ 0.30$. We again varied the pay ratio: participants were randomized to see a product sold by a retailer with either a low (5 to 1$)$ pay ratio or a high (2000 to 1) pay ratio.

Participants were again told to envision a variation of the towel context used in Study 1B, with the identical focal product description. In the high ratio condition, participants were told: "You learn that the retailer pays the average employee $\$ 22,400$. The retailer pays the CEO $\$ 48,000,000$. The ratio of the CEO's salary to the average 
employee's salary is 2000 to 1. ." In the low ratio condition, participants were told: "You learn that the retailer pays the average employee $\$ 22,400$. The retailer pays the CEO $\$ 112,000$. The ratio of the CEO's salary to the average employee's salary is 5 to $1 . ”$ Dependent Measures. Participants then completed the same willingness to buy and wage fairness measures as in Study 1B. In addition, participants were asked to report their political party from four choices (Democrat, Republican, Independent, Other). Finally, as a secondary measure, participants stated their positions regarding inequality: "Differences in income in the United States are too large (strongly agree, agree, neither agree nor disagree, disagree, strongly disagree)" ("International Social Survey Programme" 2009).

Results

Willingness to Buy. Willingness to buy from the high-pay-ratio retailer was again significantly lower than from the low-pay-ratio retailer $\left(M_{\text {low }}=5.22, S D=1.53\right.$ vs. $M_{\text {high }}$ $=4.17, S D=1.89 ; t(251)=4.84, p<0.01)$.

[Insert Figure 3 About here]

Political Beliefs. Of the participants, $18.6 \%$ identified as Republican, $44.3 \%$ identified as Democrat, $32.8 \%$ identified as Independent, and 4.3\% identified as "Other." In three of the four subgroups by political affiliation (Democrat, Independent, Other) there were significant differences in willingness to buy between the high-pay-ratio and the low-pay-ratio retailer, with participants more willing to buy in the high-pay-ratio 
condition ( $p$ 's $<0.02$; Figure 3). In the Republican subgroup, there was no significant difference in willingness to buy between the high-pay-ratio and the low-pay-ratio retailer $\left(M_{\text {low }}=5.36, S D=1.32\right.$ vs. $\left.M_{\text {high }}=5.36, S D=1.68 ; t(45)=-0.01, p=0.99\right)$.

Beliefs about Inequality. When participants were asked if differences in income in the United States are too large, 38.7\% indicated "strongly agree," $39.9 \%$ indicated "agree," 10.7\% indicated "neither agree nor disagree," 7.9\% indicated "disagree," and $2.4 \%$ indicated "strongly disagree." We conducted a 2 condition (Low Ratio, High Ratio) ANOVA on willingness to buy, including perceived differences in income as a covariate. There were main effects of condition $(F(1,248)=23.34, p<0.01)$ and perceived difference in income $(F(1,248)=22.85, p<0.01)$, and a significant interaction $(F(1,248)$ $=8.59, p<0.01)$. Participants who strongly agreed or agreed reported greater willingness to buy from low-pay-ratio retailer ( $p$ 's $<0.01$ ); participants who neither agreed nor disagreed, disagreed, or strongly disagreed reported no difference in willingness to buy $(p$ 's $>0.05)$.

Wage fairness. Perceived wage fairness was significantly lower in the high compared to the low pay ratio condition $\left(M_{\text {low }}=3.83, S D=1.80\right.$ vs. $M_{\text {high }}=2.37, S D=$ $1.58 ; t(251)=6.82, p<0.01)$.

Mediation. Pay ratio condition predicted both willingness to buy $(\beta=-1.05 p<$ $0.01)$, as well as wage fairness $(\beta=-1.45, p<0.01)$. When wage fairness and pay ratio condition were both included in the regression model predicting willingness to pay, the effect of wage fairness remained significant $(\beta=0.52, p<0.01)$, but the effect of pay ratio condition was reduced to insignificance $(\beta=-0.29, p=0.15$ ), providing support for mediation. A 5,000-sample bootstrap analysis revealed that the $95 \%$ bias-corrected 
confidence interval for the size of the indirect effect excluded zero [-1.03, -0.52$]$, suggesting a significant indirect effect (Baron and Kenny 1986; Preacher and Hayes 2008).

\section{STUDY 5: BENCHMARKING THE BENEFITS OF LOW PAY RATIOS}

Study 4 shows that Democrats and Independents respond positively to the disclosure of a low pay ratio, while Republicans are indifferent, providing evidence that the strategy increases positive perceptions of most customers without harming perceptions of other customers. In Study 5, we examine whether decreasing a good's retail price by placing the item on sale counterbalances the negative effects of revealing a high pay ratio. Study $1 \mathrm{C}$ suggested that a portion of consumers are willing to pay a price premium for a good carried by a firm with a low pay ratio, even if a competitor sells the good at a lower price. Thus, in Study 5, we assess whether the impact of high versus low pay ratios on purchase intention remains when consumers are offered increasingly attractive price discounts.

\section{Method}

Design and Procedure. Participants $\left(N=375, M_{\text {age }}=33.4,57.2 \%\right.$ male $)$ completed this online experiment in exchange for $\$ 0.30$. Participants were randomly assigned to one of 5 experimental conditions between subjects (Low Ratio, High Ratio, High Ratio $+10 \%$ discount, High Ratio $+25 \%$ discount, High Ratio $+50 \%$ discount). 
Participants were again told to envision a variation of the towel context used in Study 1A, with the identical focal product description. In the low ratio condition, participants were told: "You learn that the retailer pays the average employee $\$ 22,400$. The retailer pays the CEO $\$ 112,000$. The ratio of the CEO's salary to the average employee's salary is 5 to $1 . "$

In the high ratio condition, participants were told: "You learn that the retailer pays the average employee $\$ 22,400$. The retailer pays the CEO $\$ 24,000,000$. The ratio of the CEO's salary to the average employee's salary is 1000 to 1. "In the three new high pay ratio conditions, participants were told: "The towel is on sale for (\$45.00/\$37.50/\$25.00).” (These prices represent discounts of 10\%, 25\%, and 50\% respectively.)

Dependent Measures. Participants indicated their willingness to buy the towels and their perception of wage fairness using the same items from Study 1B.

[Insert Figure 4 About here]

Results

Willingness to Buy. We conducted a 5 condition (Low Ratio, High Ratio, High Ratio $+10 \%$ discount, High Ratio $+25 \%$ discount, High Ratio $+50 \%$ discount) ANOVA on willingness to buy (Figure 4). There was a main effect of condition $(F(4,371)=6.41, p$ $<0.01)$. We subsequently compared the various "high ratio" conditions to the "low ratio" conditions. Consistent with previous experiments, willingness to buy was significantly higher when a 5 to $1 \mathrm{CEO}$ pay ratio was disclosed versus a 1000 to $1 \mathrm{CEO}$ pay ratio $\left(M_{\text {low }}\right.$ $=4.39, S D=1.80$ vs. $\left.M_{\text {high }}=3.25 S D=1.83 ; t(147)=3.80, p<0.01\right)$. Willingness to 
buy remained significantly higher in the low-pay-ratio condition compared to a high-payratio retailer who offered a $10 \%$ price discount $\left(M_{\text {low }}=4.39, S D=1.80\right.$ vs. $M_{\text {high }}+10 \%$ off $=3.01 S D=1.94 ; t(151)=4.53, p<0.01)$, and even a high-pay-ratio retailer who offered a $25 \%$ price discount $\left(M_{\text {low }}=4.39, S D=1.80\right.$ vs. $M_{\text {high }+25 \% \text { off }}=3.69 S D=1.98 ; t(151)$ $=2.26, p<0.05)$. Only when offering a $50 \%$ price discount did a high-pay-ratio retailer elicit similar willingness to buy as the low-pay-ratio retailer $\left(M_{l o w}=4.39, S D=1.80\right.$ vs. $M_{\text {high }}+50 \%$ off $\left.=4.02 S D=2.02 ; t(153)=1.17, p=0.25\right)$.

Wage Fairness. We conducted a 5 condition (Low Ratio, High Ratio, High Ratio $+10 \%$ discount, High Ratio $+25 \%$ discount, High Ratio $+50 \%$ discount) ANOVA on perceptions of wage fairness. There was a main effect of condition $(F(4,371)=11.16, p<$ 0.01). We subsequently compared the various high ratio conditions to the low ratio condition. Wage fairness was significantly higher for low-pay-ratio retailers than highpay-ratio retailers, and this pattern held true regardless of which discount was offered (all $p$ 's $<0.01$ ); even when a high pay ratio was coupled with a $50 \%$ price discount, participants continued to rate the firm as having less fair wages $\left(M_{\text {low }}=3.63, S D=1.87\right.$ vs. $M_{\text {high }}+50 \%$ off $\left.=2.46 S D=1.46 ; t(153)=4.35, p<0.01\right)$.

Study 4 suggests that the capacity for low pay ratios to boost willingness to buy persists even if a product is offered at up to a $25 \%$ discount. Even at a $50 \%$ discount, consumers are not significantly more willing to purchase a product sold by a retailer with a high pay ratio than from a retailer with low pay ratio - but no discount at all. 
We opened by noting that Section 953(b) of the Dodd-Frank Act decreed that all public companies disclose the ratio of CEO compensation to the compensation of the median employee. We examined the impact of such disclosures on consumer behavior. Six experiments demonstrated that the disclosure of a firm's pay ratio can influence consumer purchase intention. The disclosure of a high pay ratio versus a low pay ratio leads to decreased willingness to buy and willingness to pay for a good (Studies 1A, 1B, and 1C). These effects hold across different product categories and price ranges (Studies $2 \mathrm{~A}$ and $2 \mathrm{~B}$ ). Relative to a high pay ratio, the disclosure of a low pay ratio positively increases consumer perceptions of firm warmth without sacrificing perceptions of firm competence (Study 3). Moreover, the disclosure of a low pay ratio versus a high pay ratio improves perceptions of most consumers without alienating any customer subgroups by political affiliation (Study 4). The negative effect of a high pay ratio persists in the presence of a price discount of up to $25 \%$, and only diminishes (but does not reverse) at a $50 \%$ price discount (Study 5). Across our studies, we find that perceptions of wage fairness mediate the effect of revealing pay ratio consumer purchase decisions.

Prior research examining consumer expectations of equity and price fairness has not addressed wage fairness, and whether consumers care about the distribution of wages a firm pays its employees - thus, our results contribute to both these streams of literature (Darke and Dahl 2003; Xia et al. 2004). Our results also contribute to a broader literature on the benefits of firm transparency - of firms literally showing consumers what happens behind the scenes (Buell and Norton 2011; Chinander and Schweitzer 2003). In Buell and Norton (2011), for example, consumers preferred websites that "revealed" the process by which they searched for results - in one study, revealing the process through which it 
looked for potential dates for online dating users. At the same time, however, not all disclosure proves to be beneficial: when websites reveal their processes only to suggest poor options (say, an unattractive date), consumers react more negatively. Despite the differences between dating and compensation, our results also suggest that pay disclosure can have benefits: firms with low pay ratios stand to garner improved consumer perceptions via disclosure relative to firms with very high ratios.

We note that, because pay ratio disclosure is currently not required of public companies, the estimated pay ratios informing our experiments are based on data - often self-reported - collected by third parties like Payscale (e.g., Bach 2013). Actual ratios can vary significantly on the basis of underlying assumptions when calculating both the numerator and denominator. For instance, pay ratios vary depending on whether the definition of "CEO compensation" includes stock grants, or only cash. In addition, "total compensation" might not include other benefits such as healthcare. We do not explicitly differentiate between cash and stock compensation in our studies. At the extreme end, Google's CEO Larry Page receives annual cash compensation of $\$ 1$, and has not received a stock grant in the past few years, resulting in a pay ratio that is effectively zero, regardless of employee wages ("Google Inc." 2015). We do not test these extreme cases in our research, but future research should explore consumer perceptions when CEOs appear to be trying to "dodge" disclosure by shifting their compensation toward categories that are immune from disclosure.

Given our results, it is plausible that other types of disclosures that signal wage unfairness could also affect consumer purchase intentions. One possible context for further exploration is gender inequality in wages within a company. Unlike pay ratio 
disclosure, there is no pending legislation requiring companies to disclose whether men and women doing the same job within a firm are receiving equal pay. However, in 2014, the ratio of women's to men's median weekly full-time earnings was 82.5 percent (Hegewisch, Ellis, and Hartmann 2015). While some statistics comparing salaries by gender at the firm level are available, they are both limited and self-reported (Glassdoor 2014). In 2014, Sony Pictures was hacked, and confidential internal data was made public; among other salacious findings, it was discovered that a female executive made $65 \%$ of the salary of a male executive with the same title and position (Roose 2014). If such information was representative of the gender wage gap within the whole firm, would consumers care? Thus, future research could further explore the repercussions of ratio disclosure on consumer behavior in other wage-related contexts.

\section{Conclusion}

Critics of the pay ratio disclosure law have argued that the costs of calculating the required pay ratios outweigh the economic benefits of disclosure to investors (Ross Sorkin 2015): in an open letter urging the SEC to reconsider the pay ratio rule, representatives from 33 public companies stated: "We want to emphasize our collective view that the cost of this disclosure far outweighs any benefit to the investment community" (Nelson et al. 2013). Proponents of pay ratio disclosure, in contrast, emphasize the material benefits to investors: in an open letter urging the SEC to finalize the pay ratio disclosure rule, 58 members of Congress noted that, "Boards of directors, investors, and other stakeholders need this information to better understand and assess CEO compensation" (Ellison et al. 2015). Our results demonstrate an additional impact 
that has not been widely discussed: consumers are likely to be influenced by pay ratio disclosure. Even if pay ratio disclosure does not become legally mandated, our results suggest that firms with (low) pay ratios relative to competitors may wish to begin to disclose this information voluntarily, as a means of garnering favorable consumer perceptions. 


\section{REFERENCES}

Aaker, Jennifer, Kathleen D. Vohs, and Cassie Mogilner (2010), "Nonprofits Are Seen as Warm and For Profits as Competent: Firm Stereotypes Matter," Journal of Consumer Research, 37 (2), 224-37.

AFL-CIO (2014), "Executive Paywatch,” (accessed April 9, 2015), [available at http://www.aflcio.org/Corporate-Watch/Paywatch-2014 ].

Bach, Aubrey (2013), "PayScale Presents CEO Pay in Perspective," (accessed May 17, 2015), [available at http://www.payscale.com/career-news/2013/04/payscale-presentsceo-pay-in-perspective ].

Baron, Reuben M. and David A. Kenny (1986), "Moderator-Mediator Variables Distinction in Social Psychological Research: Conceptual, Strategic, and Statistical Considerations," Journal of Personality and Social Psychology, 51 (6), 1173-82.

Bolton, Lisa E., Luk Warlop, and Joseph W. Alba (2003), “Consumer Perceptions of Price (Un) Fairness," Journal of Consumer Research, 29 (4), 474-91.

Buell, Ryan W. and Michael I. Norton (2011), “The Labor Illusion : How Operational Transparency Increases Perceived Value,” Management Science, 57 (9), 1564-79.

Campbell, Margaret C. (1999), "Perceptions of Price Unfairness: Antecedents and Consequences," Journal of Marketing Research, 36 (2), 187-99. 
Chinander, Karen R. and Maurice E. Schweitzer (2003), "The Input Bias: The Misuse of Input Information in Judgments of Outcomes," Organizational Behavior and Human Decision Processes, 91 (2), 243-53.

“Comments on Pay Ratio Disclosure" (2013), (accessed April 9, 2015), [available at https://www.sec.gov/comments/s7-07-13/s70713.shtml ].

Crockett, David and Melanie Wallendorf (2004), "The Role of Normative Political Ideology in Consumer Behavior,” Journal of Consumer Research, 31 (3), 511-28.

Darke, Peter R. and Darren W. Dahl (2003), “Fairness and Discounts: The Subjective Value of a Bargain," Journal of Consumer Psychology, 13 (3), 328-38.

Davidoff, Solomon (2013), “A Simple Solution That Made a Hard Problem More Difficult,” (accessed April 9, 2015), [available at http://dealbook.nytimes.com/2013/08/27/a-simple-solution-that-made-a-hard-problemmore-difficult/].

Ellison, Keith et al. (2015), “Comment Letter,” (accessed April 9, 2015), [available at https://www.sec.gov/comments/s7-07-13/s70713-1550.pdf].

Glassdoor (2014), “The Gender Pay Gap Revealed in Tech,” (accessed May 25, 2015), [available at http://www.glassdoor.com/blog/tech-salaries-glassdoor-diversity-hiringsurvey/].

“Google Inc.” (2015), (accessed April 9, 2015), [available at http://insiders.morningstar.com/trading/executive-compensation.action?t=GOOG ]. 
Hegewisch, Ariane, Emily Ellis, and Heidi Hartmann (2015), “The Gender Wage Gap: 2014; Earnings Differences By Race and Ethnicity,” [available at http://www.iwpr.org/publications/pubs/the-gender-wage-gap-2014-earnings-differencesby-race-and-ethnicity].

Hirschman, Elizabeth C. (1993), "Ideology in Consumer Research, 1980 and 1990: A Marxist and Feminist Critique," Journal of Consumer Research, 19 (4), 537-55.

Hiscox, Michael J., Michael Broukhim, and Claire S. Litwin (2015), “Consumer Demand to Fair Trade: New Evidence from a Field Experiment Using Ebay Auctions of Fresh Roasted Coffee,” working paper, Harvard University..

Hsee, Christopher K. (1996), “The Evaluability Hypothesis: An Explanation for Preference Reversals Between Joint and Separate Evaluestions of Alternatives," Organizational Behavior and Human Decision Processes, 67 (3), 247-57.

Huppertz, John W., Sidney J. Arenson, and Richard H. Evans (2013), “Application of Equity Buyer-Seller Exchange Theory Situations," 15 (2), 250-60.

"International Social Survey Programme” (2009), ISSP 2009 Social Inequality IV, [available at http://www.gesis.org/en/issp/issp-modules-profiles/social-inequality/2009/].

Kahneman, Daniel, Jack L. Knetsch, and Richard Thaler (1986), "Fairness as a Constraint on Profit Ceeking: Entitlements in the Market," The American Economic Review, 76 (4), 728-41. 
Kiatpongsan, Sorapop and Michael I. Norton (2014), "How Much (More) Should CEOs Make? A Universal Desire for More Equal Pay," Perspectives on Psychological Science, $9(6), 587-93$.

Kidwell, Blair, Adam Farmer, and David M. Hardesty (2013), "Getting Liberals and Conservatives to Go Green: Political Ideology and Congruent Appeals," Journal of Consumer Research, 40 (2), 350-67.

Kimeldorf, Howard, Rachel Meyer, and Ian Robinson (2004), "Consumers of the World Unite : A Market-based Response to Sweatshops,” 29 (3), 57-79.

Kuziemko, Ilyana, Michael I. Norton, Emmanuel Saez, and Stefanie Stantcheva (2015), "How Elastic Are Preferences for Redistribution? Evidence from Randomized Survey Experiments," American Economic Review, 4 (105), 1478-1508.

McGregor, Jena (2013), “What's the Right Ratio for CEO-to-Worker Pay?," (accessed April 9, 2015), [available at http://www.washingtonpost.com/blogs/onleadership/wp/2013/09/19/whats-the-right-ratio-for-ceo-to-worker-pay/].

Morgensen, G. (2015), “Despite Federal Regulation, C.E.O.-Worker Pay Gap Data Remains Hidden," (accessed April 10, 2015), [available at http://www.nytimes.com/2015/04/12/business/despite-federal-regulation-ceo-workerpay-gap-data-remains-hidden.html?mabReward=A3\&_r=1 ].

Nelson, Keith et al. (2013), “Comment Letter,” (accessed April 9, 2015), [available at https://www.sec.gov/comments/s7-07-13/s70713-660.pdf ]. 
Norton, Michael I. and Dan Ariely (2011), "Building a Better America--One Wealth Quintile at a Time," Perspectives on Psychological Science, 6 (1), 9-12.

Okada, Erica M. (2005), “Justification effects on consumer choice of hedonic and utilitarian goods," Journal of Marketing Research, 42 (1), 43-53.

Paharia, Neeru, Kathleen D. Vohs, and Rohit Deshpandé (2013), “Sweatshop Labor is Wrong Unless the Shoes are Cute: Cognition can both Help and Hurt Moral Motivated Reasoning," Organizational Behavior and Human Decision Processes, 121 (1), 81-88.

PayScale (2013), “Fortune 100's CEO to Employee Incomes Compared,” (accessed April 9, 2015), [available at http://www.payscale.com/career-news/2013/04/payscale-presentsceo-pay-in-perspective ].

Preacher, Kristopher J. and Andrew F. Hayes (2008), “Asymptotic and Resampling Strategies for Assessing and Comparing Indirect Effects in Multiple Mediator Models," Behavior Research Methods, 40 (3), 879-91.

Roose, Kevin (2014), “Hacked Documents Reveal a Hollywood Studio’s Stunning Gender and Race Gap,” (accessed April 9, 2015), [available at http://fusion.net/story/30789/hacked-documents-reveal-a-hollywood-studios-stunninggender-and-race-gap/ ]

Ross Sorkin, Andrew (2015), “S.E.C. Has Yet to Set Rule on Tricky Ratio of C.E.O.'s Pay to Workers'," (accessed April 9, 2015), [available at 
http://dealbook.nytimes.com/2015/01/26/tricky-ratio-of-chief-executives-pay-toworkers/?_r=0].

“The Dodd-Frank Act" (2010), (accessed April 9, 2015), [available at http://www.doddfrank-act.us/Dodd_Frank_Act_Text_Section_953.html].

Winterich, Karen Page, Yinlong Zhang, and Vikas Mittal (2012), "How Political Identity and Charity Positioning Increase Donations: Insights from Moral Foundations Theory," International Journal of Research in Marketing, 29 (4), 346-54.

Xia, Lan, Kent B. Monroe, and Jennifer L. Cox (2004), “The Price Is Unfair! A Conceptual Framework of Price Fairness Perceptions,” Journal of Marketing, 68 (4), 115. 


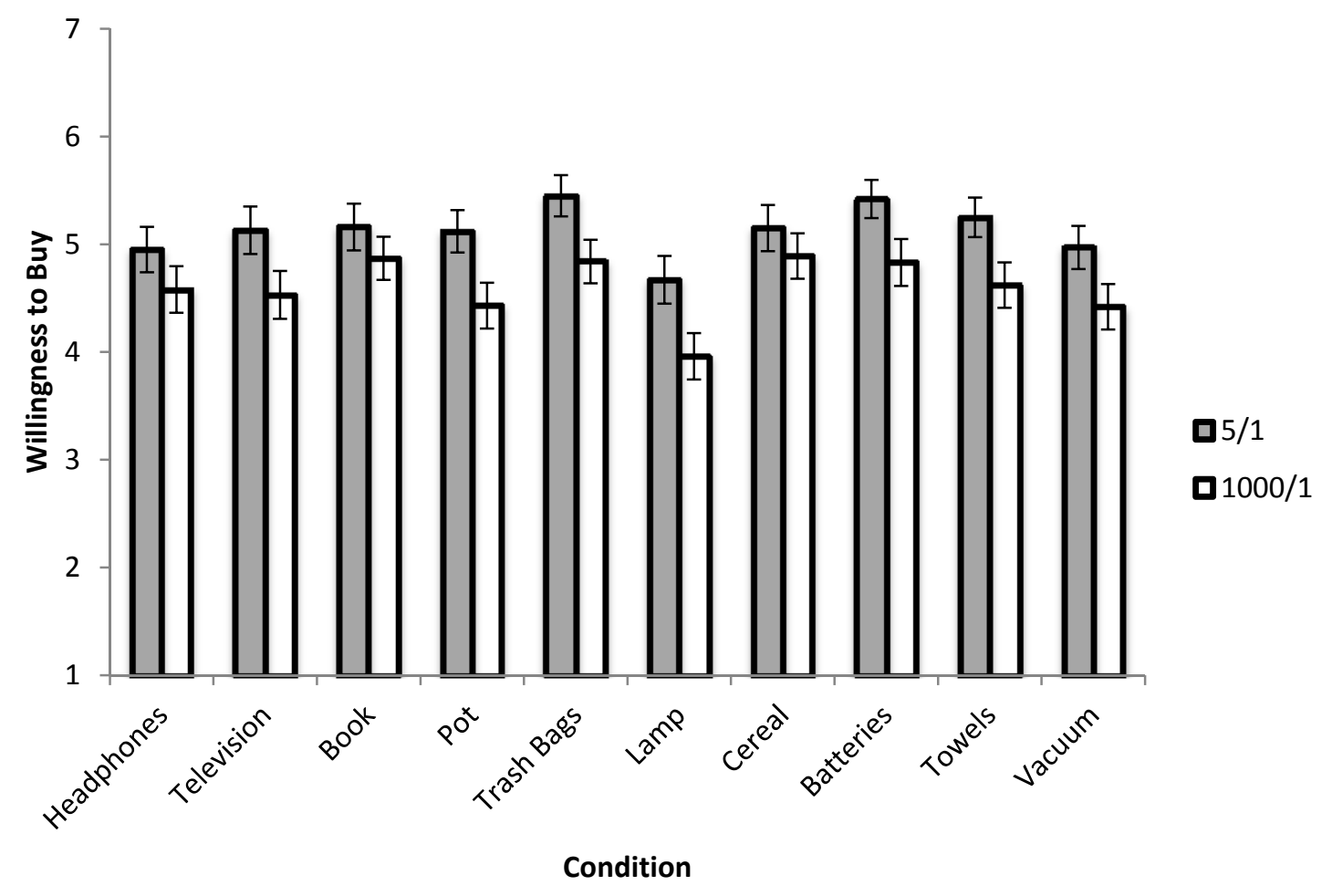

Figure 1. Consumers are more willing to buy a wide range of products from retailers with low pay ratios (Study 2A). 


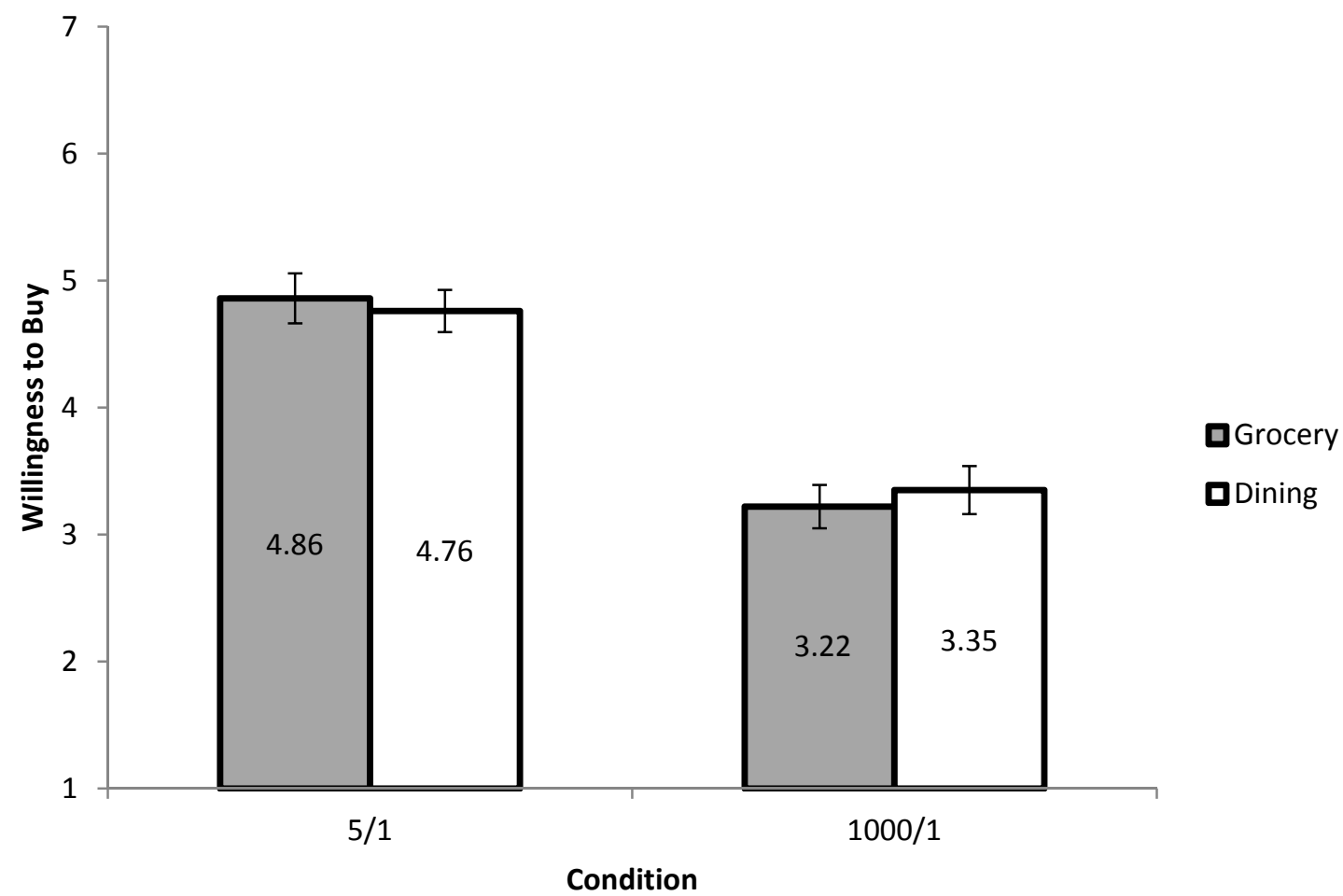

Figure 2. Consumers are more willing to buy gift cards for both hedonic and utilitarian goods from retailers with low pay ratios (Study 2B). 


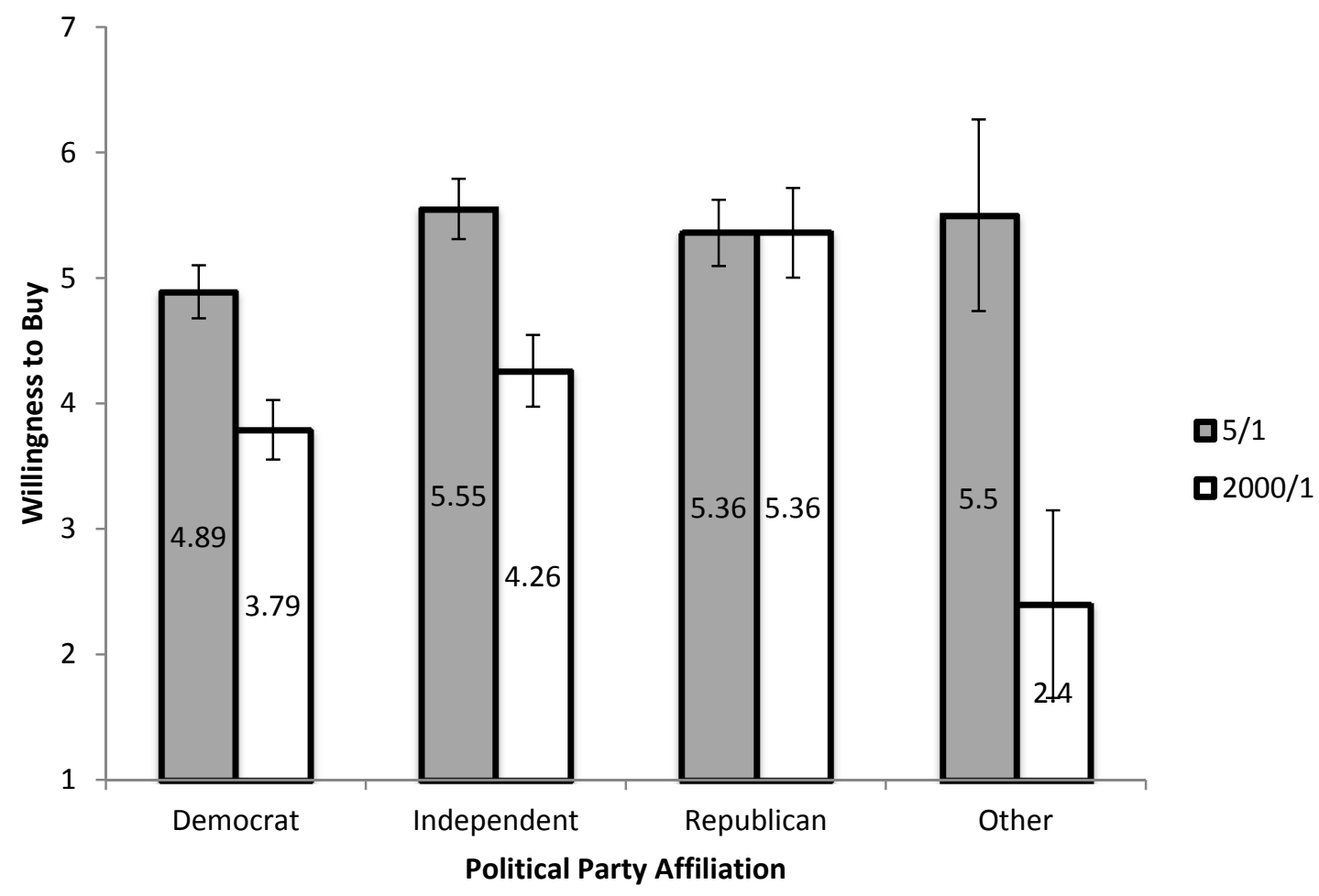

Figure 3. Most consumer subgroups, by political party, are more willing to buy from retailers with low pay ratios (Study 4). 


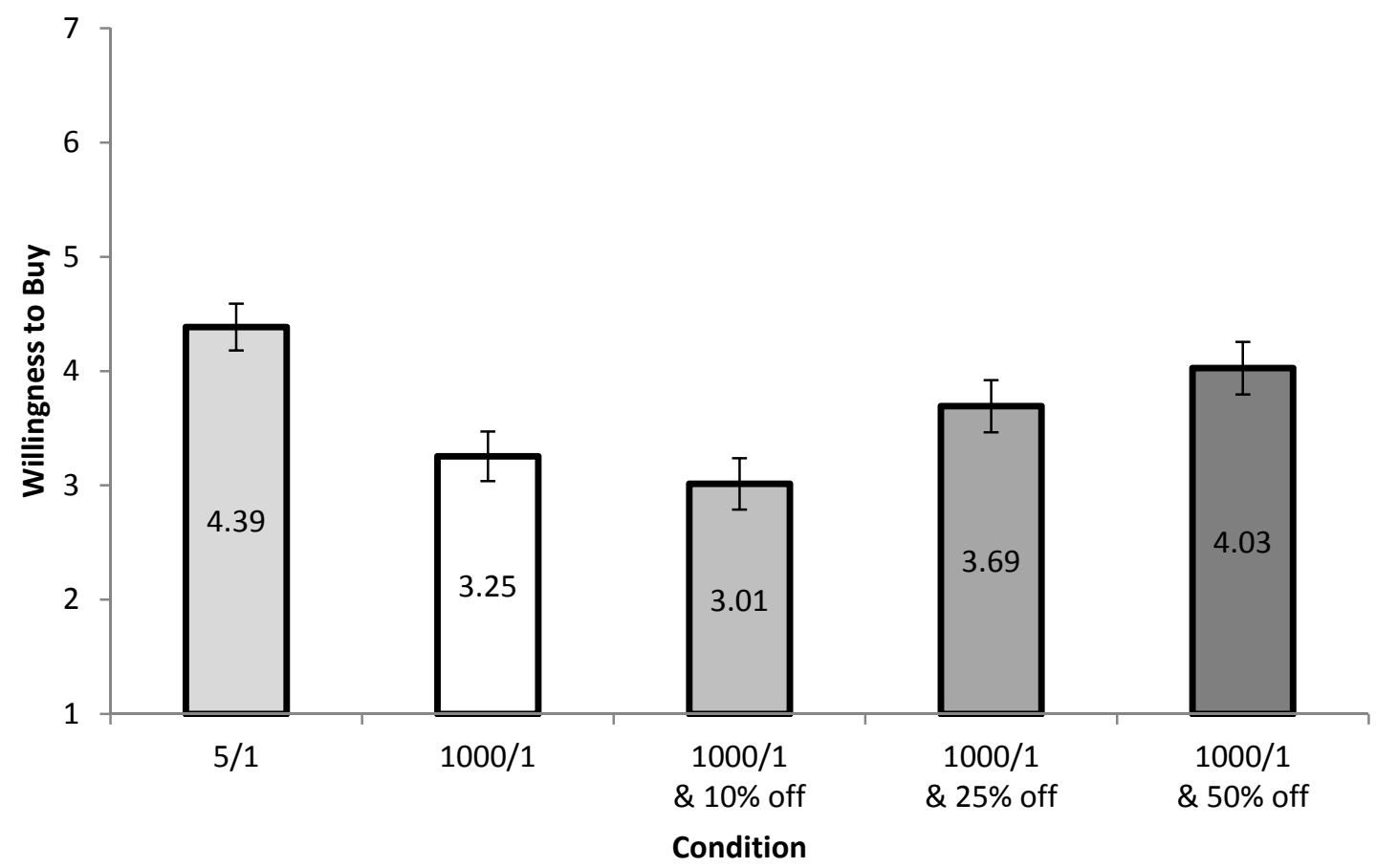

Figure 4. Firms with high pay ratios must offer a $50 \%$ discount in order for consumers to be as willing to buy from them as from a retailer with a low wage ratio (Study 5). 